\title{
TECHNOLOGICAL PROPERTIES OF LATEX AND NATURAL RUBBER OF Hevea brasiliensis CLONES
}

\author{
Rogério Manoel Biagi Moreno; Mariselma Ferreira²; Paulo de Souza Gonçalves³; \\ Luiz Henrique Capparelli Mattoso ${ }^{1 *}$ \\ ${ }^{1}$ Embrapa Instrumentação Agropecuária, C.P. 74 - 13560-970 - São Carlos, SP - Brasil. \\ ${ }^{2}$ USP - Interunidades em Ciência e Engenharia de Materiais - 13566-590 - São Carlos,SP - Brasil. \\ ${ }^{3}$ IAC, C.P. 28 - 13020-902 - Campinas, SP - Brasil. \\ *Corresponding author <mattoso@cnpdia.embrapa.br>
}

\begin{abstract}
Rubber industry has increased the requirements for quality and uniformity of natural rubber produced in Brazil. Technological properties of latex and natural rubber of clones GT 1, PB 235, IAN 873 and RRIM 600 [Hevea brasiliensis (Willd. Former Adr. de Juss.) Muell.- Arg] were evaluated by standard methods of the dry rubber content (DRC\%), percentage of nitrogen (N\%) and percentage of ashes (ASH\%) in two consecutive years; data were correlated with temperature and precipitation. Properties of latex and natural rubber varied $(P<0.01)$ as a function of clone type and among tappings. DRC decreased in the beginning of the dry season (May to June) and N\% and ASH\% increased in the same period. April to June was a critical period, when N\% was above $0.60 \%$, out of standards established by the technical standard ABNT/NBR in Brazil. Clone RRIM 600 was less susceptible to climatic variations.

Key words: rubber tree, standard methods, productivity, environmental conditions
\end{abstract}

\section{PROPRIEDADES TECNOLÓGICAS DO LÁTEX E DA BORRACHA NATURAL DE CLONES DE Hevea brasiliensis}

\begin{abstract}
RESUMO: A indústria da borracha está cada vez mais exigente em relação à qualidade e a uniformidade da borracha natural produzida no Brasil. Neste trabalho as propriedades tecnológicas do látex e da borracha natural dos clones de seringueira GT 1, PB 235, IAN 873 e RRIM 600 [Hevea brasiliensis (Willd. ex Adr. de Juss.) Muell.-.Arg] foram avaliadas pelos ensaios padrões do conteúdo de borracha seca (DRC\%), porcentagem de nitrogênio (N\%) e porcentagem de cinzas (CNZ\%) por dois anos consecutivos; os dados obtidos foram correlacionados com dados de temperatura e precipitação. As propriedades do látex e da borracha natural variaram $(P<0.01)$ em função do tipo de clone e entre coletas. O DRC\% diminuiu no início da estação seca (maio a junho), enquanto N\% e CNZ\% aumentaram. O período de abril a junho revelou ser crítico, pois os valores da N\% oscilaram acima 0,60\%, fora dos padrões estabelecidos pela norma técnica brasileira ABNT/ NBR. O clone RRIM 600 foi menos suscetível às variações climáticas.

Palavras-chave: seringueira, ensaios padrões, produtividade, condições climáticas
\end{abstract}

\section{INTRODUCTION}

Brazil has already been one of the major producers and exporters of natural rubber (NR) in the world. However, the country contributed with only $1 \%$ of the world production - 7.970 thousand tons - in 2003 (International Rubber Study Group, 2004). According to official data from CONAB, for the year 2002, the production of natural rubber in the country is insufficient to meet internal demand. It is thus necessary to import around $60 \%$ of the total rubber consumed in Brazil - 250 thousand tons.

Because of its mechanical properties, natural rubber is an important and strategic raw material for the tire and electric industries. Quality and property of the natural rubber depend, in part, on the quantities of non-rubber elements in the latex (Yip, 1990; Haque et al., 1995; Le Roux et al., 2000). In addition, the technological prop- erties of the natural rubber vary according to the time of shelf life, type of coagulation, time of year and clonal origin (Le Roux et al., 2000; Ferreira et al., 2002; Moreno et al., 2003).

Brazilian rubber-transformation industry abides by strict quality and uniformity standards. Embrapa Instrumentação Agropecuária, in association with Instituto Agronômico (IAC), routinely assesses effects of season and climate conditions in the quality and uniformity of natural rubber to help selecting new clones for large scale plantations in the State of Sao Paulo, Brazil's largest planted region $-49 \%$ of the country's production, or $105.000 \mathrm{t}$. The objective of this study was assessing effects of clone type, harvest period and climate in the productivity and technological properties of the latex and natural rubber harvested out of clones of great use in the State of Sao Paulo. 


\section{MATERIAL AND METHODS}

Rubber tree secondary clones PB 235, IAN 837 and RRIM 600, and primary clone GT 1, recommended for large scale plantations Southeast Brazil, were assessed from January, 1989 to 1996, in an Eutrudult (20'20'S; $49^{\circ} 58$ ' $\mathrm{W}$; altitude $510 \mathrm{~m}$ ) Trials were set up in a randomized block design, with 20 plants per plot $(n=3)$.

Region's climate is predominantly continental tropical, with rainy summer, typical tropical energy levels, and dry winter with hydric deficiencies, low temperatures and reduced rainfall (June to early September). A parallel between the monthly rain and evapotranspiration curves, results in propitious equilibrium for plant growth from October to March.

Technological properties of the latex and natural rubber were evaluated for two years, resulting in forty tappings along 2000 and 2001. Twelve trees of each of the four clones were tapped, and technological properties of the latex and natural rubber were evaluated by the standard methods of the dry rubber content in the latex (DRC\%), percentage of nitrogen (N\%) and percentage of ashes (ASH\%), recommendation ABNT-NBR 11597 (Associação Brasileira de Normas Técnicas - ABNT, 1997).

The tapping procedure was: half spiral $(1 / 2 \mathrm{~S})$, every four-day (d/4), five days a week (5d/7), for 11 months over the year $(11 \mathrm{~m} / \mathrm{y})$. Trees were stimulated with $2.5 \%$ of the active ingredient ethephon (ET 2.5\%), applied by daub in the tapping panel $(\mathrm{Pa})$, eight times a year $(8 / y)$.

The rubber production of the clones was obtained in two out of the eight monthly tappings, in 12 trees per plot. Coagulated latex was weighted, and dried in the shade under natural ventilation. Latex productivity was expressed as $g$ tree $^{-1}$ bleeding $^{-1}$. Final average productivity was calculated at the end of the experimental period. Data were submitted to ANOVA and "Stepwise" multiple regression analysis using the statistical package SAS.

\section{RESULTS AND DISCUSSION}

There were differences for the properties DRC\% $(P<0.01)$, N\% $(P<0.05)$, ASH\% $(P<0.01)$, and productivity $(P<0.01)$ between latex harvests and clones (Table 1).

\section{Productivity of the Clones}

The productivity of all clones increased along the first semester, both years; decreasing started in May (Figure 1). Generally, maximum productivity happens in April and May, when plants have available the maximum of the assimilated and latex production is free from competition of nutrient drainage of leaves and fruits (Gonçalves et al., 1991).
Table 1 - Mean square of the standard assays related to the quantity of dry rubber in the latex dry rubber content (DRC\%), percentage of nitrogen (N\%), percentage of ashes (ASH\%) and productivity of the four rubber tree clones.

\begin{tabular}{lccc}
\hline \multirow{2}{*}{$\begin{array}{l}\text { Standard } \\
\text { tests }\end{array}$} & \multicolumn{3}{c}{ Mean square } \\
\cline { 2 - 4 } DRC\% & $54.813 * *$ & $70.123 * *$ & 5.633 \\
Ash\% & $0.0264 * *$ & $0.005 *$ & 0.003 \\
N\% & $0.0323 * *$ & $0.036 * *$ & 0.0023 \\
Productivity & $14300.813 * *$ & $55487.442 * *$ & 2627.940 \\
\hline
\end{tabular}

${ }^{1}$ The degree of freedom of harvest, clone and residue are 39.3 and 117 respectively;

$*$ and $* *$ - significant to $5 \%$ and $1 \%$, respectively.

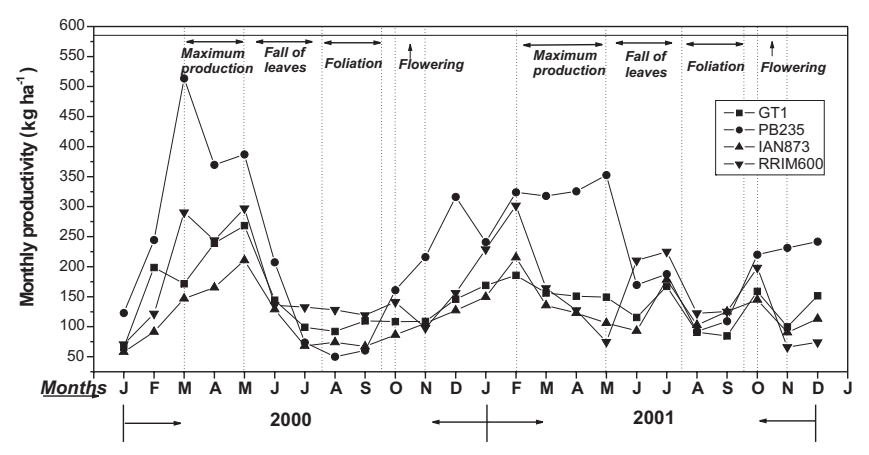

Figure 1 - Monthly productivity, years 2000 and 2001, of the four studied rubber clones tree.

Clone PB 235 had the best dry rubber production, but also the largest variation, followed by the clone RRIM 600 . Clones GT 1 and IAN 873 had similar values. Clone PB 235 reached maximum productivity sometime before the other clones, and remained in a superior level of productivity; clone RRIM 600 followed. The smaler productivity of clone PB 235 happened along maximum senescence, and can be associated to the completion of the falling process.

The highest productivity was reached by clone RRIM 600, which presents partial senescence. Even though this clone uses large quantities of assimilated material from the foliation to the flowering, its productivity grows gradually. Favored by phenological processes, clone PB 235 presents faster, early enlargement, in comparison to the other clones.

Variations in the productivity along phenological cycles of rubber trees are related to water availability and thermal conditions, and except for atypical years of hydric stress or phytosanitary problems, rubber trees reach maximum leaf area and begin fruitage in early November (Gonçalves et al., 1991). By late February, dehiscence of the fruits begins, and so does productivity of the latex. This phenomenon was observed for the four clones, but clone PB 235 presented superior productivity. 


\section{Quality of the latex of natural rubber}

Dry rubber content (DRC\%) - The DRC\% is a physiological parameter of the latex, an indicator of the biosynthetic activity in the laticiferous vases (Jacob et al., 1988). From January to July, 2000, there was continuous reduction of the DRC\% (Figure 2), precipitations and temperature with growing production, reaching its apex in May, 2000. Such behavior is possibly connected to the association of the lesser availability of water in the soil and the senescence of the leaves (Serres et al., 1994) which causes decreased viscosity of the latex (Van Gils, 1951), favoring its flow and eliciting larger productivity.

The inverse correlation of DRC\% to productivity was not observed in the same period in 2001. High insolation and low temperatures in the morning may incite the regeneration and flow of latex (d'Auzac et al., 1989). In the second semester, gradual increase of the DRC\% and productivity happened, probably because of the increase in insolation (photoperiod) and milder temperatures in the morning that may have lead to the regeneration and flow of latex (d'Auzac et al., 1989), except for the productivity in the year 2001, possibly because of higher temperatures and lower precipitations.

DRC\% varied from 36.21\% (GT 1) to 33.00\% (RRIM 600). The average DRC\% of the four clones (Table 2) was a little higher than the ones reported by Moreno et al. (2003). The clone PB 235 had more distinct pattern of reduction of the DRC\% (January to June, 2000) than the other clones, probably because it had a little anticipated senescence period, as observed during the period of the latex harvest, a kind of behavior that varies among clones (Moraes, 1977) (Figure 3). The
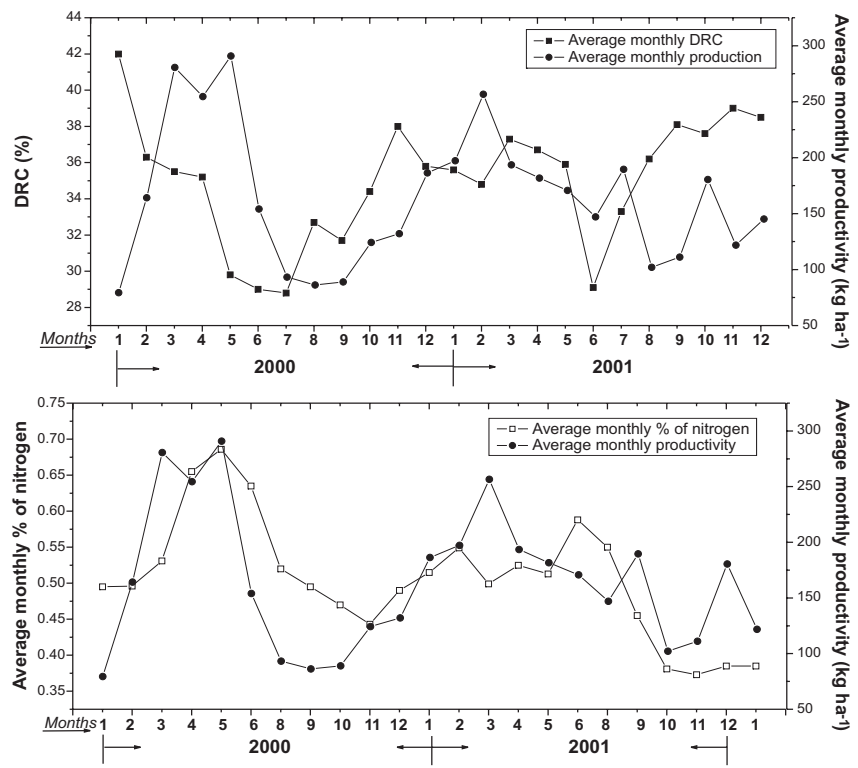

Figure 2 - Average monthly variation of the dry rubber content (DRC\%) and percentage of nitrogen (N\%) with the average monthly productivity of the four rubber tree clones. smallest values of DRC\% coincided, in general, with maximum senescence, low temperature and minimal precipitation, when smaller availability of water in the soil heavily affects not only photosynthesis efficiency but also the reactions of latex dilution, altering plants metabolism and influencing the polyisoprene biosynthetic process (d’Auzac et al., 1989), leading to low biomass production and evapotranspiration rate (Gonçalves et al., 1991). Reduction of DRC\% happened suddenly in 2001. Plants that go from colder and drier to hotter and more humid seasons, coupled to the process of foliation and flowering, use large quantities of assimilated material, and that results generally in low production of latex (Priyadarshan et al., 2001). In the periods of gradual rise
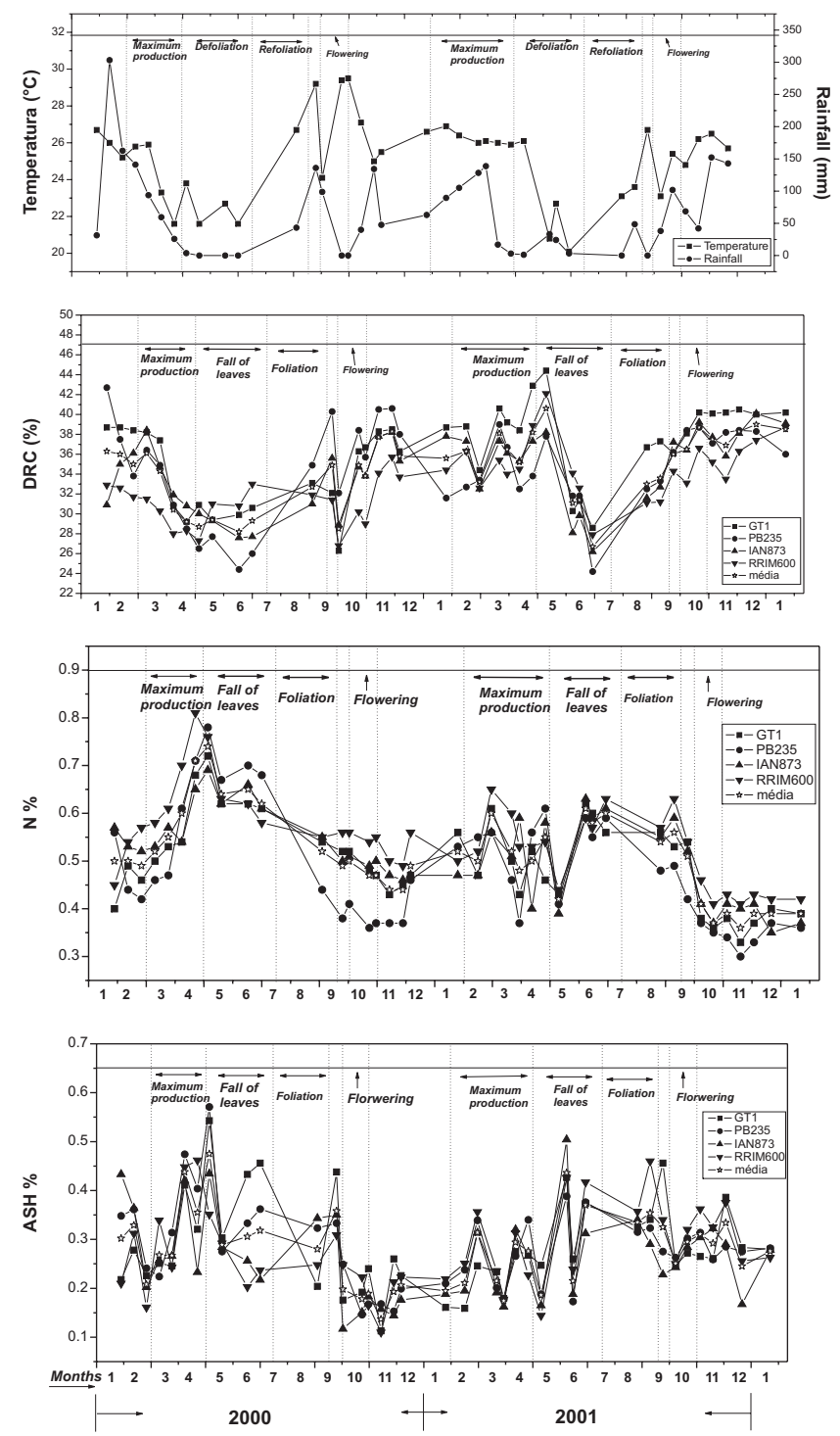

Figure 3 - Variation of the climate conditions and properties of the latex and natural rubber of the four rubber tree clones. Points of temperature and precipitations curves are average and sum of 15 days before each day of harvest, respectively. Dry rubber content (DRC\%), percentage of nitrogen (N\%), percentage of ashes (ASH\%) 
Table 2 - Averages and coefficients of variation of the properties of the latex and the natural rubber related to the dry rubber content (DRC\%), percentage of nitrogen (N\%) and percentage of ashes (ASH\%) and average annual productivity of the four rubber tree clones.

\begin{tabular}{|c|c|c|c|c|c|c|c|c|}
\hline \multirow{2}{*}{ Clone } & \multicolumn{2}{|c|}{ DRC } & \multicolumn{2}{|c|}{$\mathrm{N}$} & \multicolumn{2}{|c|}{$\mathrm{ASH}$} & \multicolumn{2}{|c|}{ Productivity $\left(\mathrm{g} \mathrm{t}^{-1} \mathrm{t}^{-1}\right)^{1}$} \\
\hline & Average & $\mathrm{CV}$ & Average & $\mathrm{CV}$ & Average & $\mathrm{CV}$ & Average & $\mathrm{CV}$ \\
\hline & - & & 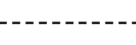 & 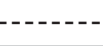 & $-\cdots-1$ & & & \\
\hline GT 1 & 36.21 & 12.21 & 0.50 & 18.00 & 0.283 & 34.947 & 39.2 & 46.9 \\
\hline PB 235 & 34.90 & 14.60 & 0.48 & 25.00 & 0.282 & 32.730 & 68.1 & 56.8 \\
\hline IAN 873 & 34.31 & 11.41 & 0.51 & 17.06 & 0.260 & 35.654 & 35.1 & 44.7 \\
\hline RRIM 600 & 33.00 & 10.00 & 0.55 & 16.18 & 0.281 & 31.851 & 46.0 & 48.7 \\
\hline Average & 34.60 & 12.11 & 0.51 & 19.06 & 0.277 & 33.800 & 47.1 & 49.3 \\
\hline $\mathrm{CV} \%$ & 3.84 & - & 5.69 & - & 3.971 & - & 31.2 & - \\
\hline
\end{tabular}

in the temperature and precipitations, that favor the biosynthetic process of the plant (Figure 3), the values of DRC\% increased gradually, in spite of the energetic draw on of foliation and flowering. The clone PB 235 had the highest values of DRC\% and the clone GT 1 presented the most stable values along 2000. In comparison to the other clones, GT 1 had the highest and most stable values of DRC\% in 2001, an indicative of better resistance to climate variations. In opposition, clone RRIM 600 had smaller values and largest variations of DRC\%. Clone IAN 873 was the most influenced by the environmental variants $\left(R^{2}=0.2609\right)$, while the clone RRIM 600 suffered the least influence (Table 3 ).

\section{Analyses at the dry rubber}

Percentage of nitrogen (N\%) - The nitrogen found in the dry rubber comes mainly from proteins and amino acids. Othman et al. (1993) showed that some amino acids, such as arginine, cause the formation of crosslinks, increasing the elasticity module of the rubber (E) - the rate between the tension applied and the deformation suffered by the material.

The average N\% had behaved similarly to the average monthly productivity - an increase in the production of dry rubber was followed by an increase in N\% (Figure 2). According to Coupé (1978), this behavior is associated to the increase in the protein biosynthesis, followed by an increase in the rubber productivity.

Clone RRIM 600 had the highest N\% average value $(0.55 \%)$ and lowest coefficient of variation $(\mathrm{CV}=$ $16.18 \%$ ) (Table 2). Clone PB 235, the most susceptible to the environmental variations, had the lowest N\% average value $(0.48 \%)$ and the largest coefficient of variations $(\mathrm{CV}=25.00 \%)$. The average values of the N\% recorded lie within specifications of NBR 11597 (Associação Brasileira de Normas Técnicas - ABNT, 1996), which allows maximum N\% $=0.60 \%$.

The N\% of the four clones tended to increase between January and May, a period of lower temperature and precipitations followed by senescence of the leaves
Table 3 - Determination coefficients $\left(\mathrm{R}^{2}\right)$ for the contributions for the environmental variants temperature and precipitations, in association, in the properties of the latex and the natural rubber. Dry rubber content (DRC\%), percentage of nitrogen (N\%) and percentage of ashes (ASH\%).

\begin{tabular}{lccc}
\hline Clone & DRC & N & ASH \\
\hline & 0.1080 & 0.2125 & 0.2333 \\
GT 1 & 0.2448 & 0.2238 & 0.1455 \\
PB 235 & 0.2609 & 0.2161 & 0.1180 \\
IAN 873 & 0.0452 & 0.0963 & 0.1121 \\
\hline
\end{tabular}

(Figure 3). That trend may be associated to the senescence of the leaves, apart from the process of increase in the protein biosynthesis. Before the abscission of the leaves, there is the removal of some mineral nutrients, among them the N, which is easily translocated (Larcher, 1995).

With the beginning of the process of foliation, flowering and fructification, the $\mathrm{N}$ absorbed by the leaves is continuously reused and the values of the N\% decrease, reaching a minimum with the flowering process in course (October) and maximum leaf area (starting November). Similar situation was also recorded for rubber plantations in the region of Matão, state of Sao Paulo (Moreno et al., 2003; Ferreira et al., 2002). Clone PB 235 was the most influenced by the environmental variants $\left(R^{2}=0.2238\right)$, while clone RRIM 600 suffered the smallest influence of the temperature and precipitation $\left(\mathrm{R}^{2}=0.0963\right)$ (Table 3).

Percentage of ashes (ASH\%) - ASH\% presented significant oscillations (Figure 3), in contrary trend to DRC\%. Recorded values of ASH\% were smaller than those reported by Yip (1990) and Haque et al. (1995). All four clones did not exceed the maximum ASH\% limit of 0.50\% approved by ABNT (1996). Values of ASH\% exceeding $0.5 \%$ were only observed in May, 2000 (GT 1 and PB 235) and May, 2001 (IAN 873). The highest average value was recorded for clone GT $1(0.28 \%)$ and the 
lowest by the clone IAN 873 (0.26\%). Regarding ASH\%, clone RRIM 600 was the least susceptible to the climate variations $\left(R^{2}=0.1121\right)$ and clone GT 1 was the most susceptibility to the climate factors $\left(\mathrm{R}^{2}=0.2333\right)$ (Table 3$)$.

There was a tendency of increasing ASH\% from January to May, 2000, triggered by variations of climate, clonal and phenological (senescence). In that period, low precipitations favored smaller availability of water in the soil, what may have led to slighter dilution of the latex which, in association with senescence, caused an increase in $\mathrm{ASH} \%$.

The elements $\mathrm{N}, \mathrm{P}, \mathrm{K}, \mathrm{Na}, \mathrm{Cl}$, and $\mathrm{S}$ are mobile, while $\mathrm{Zn}, \mathrm{Cu}, \mathrm{Mn}, \mathrm{Fe}$, and $\mathrm{Mg}$ are partially mobile (Malavolta et al., 1989). When the absorbed nutrients are reused, ASH\% tends to decrease (May), favored by increasing precipitations. Starting November, the rubber trees reach their maximum leaf area and, with flowering in course, $\mathrm{ASH} \%$ reaches its minimum. The increase of the ASH (January to May) was less evident in 2001. Possibly the accentuated variation in the precipitations led to a less homogeneous behavior.

There were accentuated variations $(P<0.01)$ among the clones for all the properties evaluated, except for the ASH\% $(P<0.05)$. Variations were also accentuated $(P<0.01)$ for all the properties between tappings. From the perspective of the uniformity of the properties along the year, the DRC\% varied the least. However, uniform behavior along the year does not correspond to the ideal targeted by industry of the latex of natural rubber, that is linearity of values over the years.

Environmental variants (temperature and precipitation) exert distinct influence on the variations of the technological properties of the clones evaluated, but the intrinsic characteristics of each clone elicit different responses to the climate variations. Clone RRIM 600 has the least susceptibility to the climate variations, regarding all properties.

Apart from the distinct climate behavior in the two years of tappings, the clone PB 235 was the most productive. From its foliation forth, PB 235 was the most vigorous and had more accentuated increase of productivity. The clone IAN 873 had the most homogeneous productivity of all.

The period from April to June was critical, both years. In that period, values of N\% above $0.60 \%$, established by the rule ABNT/NBR 11597, were recorded for all clones. A strong influence of the phenological processes of senescences and foliation is evident on the behavior of rise and fall of $\mathrm{N} \%$, respectively.

On average, none of the clones exceeded the maximum limit of $0.50 \%$ of ashes, rate recommended by the rule ABNT/NBR 11597 for good quality rubber. The latex and the natural rubber of the four clones evaluated present good quality and meet specifications for industrial application.

\section{ACKNOWLEDGEMENTS}

\section{To FAPESP and CNPq, by the financial support. \\ REFERENCES}

ASSOCIAÇÃO BRASILEIRA DE NORMAS TÉCNICAS. Borracha natural: NBR 11597. Rio de Janeiro, 1996. 22p.

COUPÉ, M. Biosynthese des proteines du latex, facteur de la production de l'Hevea. Caoutchoucs et Platiques, v.579, p.91-95, 1978.

D’AUZAC, J.; JACOB, J.L.; CHRESTIN, H. Physiology of rubber tree latex. 1.ed. Boca Raton: CRC Press, 1989. 469p.

FERREIRA, M.; MORENO, R.M.B.; GONÇALVES, P. de S.; MATTOSO, L.H.C. Evaluation of natural rubber from clones of Hevea brasiliensis. Rubber Chemistry and Technology, v.75, p.1-7, 2002.

GONÇALVES, P. de S.; CARDOSO, M.; BOAVENTURA, M.A.M.; COLOMBO, C.A.; ORTOLANI A.A. Clones de Hevea: Influência dos fatores ambientais na produção e recomendação para plantio. Campinas: Instituto Agronômico de Campinas, 1991. 32p. (Boletim Técnico, 138).

HAQUE, M.E.; AKHTAR F; DAFADER N.C.; Al-SIDDIQUE F.R. Characterization of natural rubber latex concentrate from Bangladesh. Macromolecules Reports, v.32, p.435-445, 1995.

INTERNATIONAL RUBBER STUDY GROUP (Wembley, Grã-Bretanha). Production and consumption of natural rubber. Natural Rubber Statistical Bulletin, v.58, p.9-18, 2004.

JACOB, J.L.; PREVOT, J.C.; ESCHBACH, J.M.; LACROTTE, R.; SERRES, E.; VIDAL, A. In: INTERNATIONA CONGRESS OF PLANT PHYSIOLOGY, New Delhi, 1988. Proceedings. New Delhi: Rubber Research Institute of India, 1988. p.15-20.

LARCHER, W. Physiological plant ecology. Berlin: Springer-Verlag, 1995.

LE ROUX, Y.; EHABE, E.; SAINTE-BEIVE, J.; NKENGAGAC, J.; NKENG, J.; NGOLEMASANGO, F.; GOBINA, S. Seasonal and clonal variation in the latex and raw rubber of Hevea brasiliensis. Journal of Rubber Research, v.3, p.142-156, 2000.

MALAVOLTA, E.; VITTI, G.C.; OLIVEIRA, S.A. Avaliação do estado nutricional das plantas. São Paulo:EDUSP, 1989.

MORAES, V.H.F. Rubber. In: ALVIN, P. de T.; KOZLOWSKI, T.T. (Ed.) Ecophysiology of tropical crops. New York: Academic Press, 1977. cap.3.

MORENO, R.M.B.; FERREIRA, M.; GONÇALVES P. de S.; MATTOSO, L.H.C. Avaliação do látex e da borracha natural de clones de seringueira no Estado de São Paulo. Pesquisa Agropecuária Brasileira, v.38, p.583590, 2003

OTHMAN, A.B.; HEPBURN, C.; HASMA, H. Influence of non-rubber constituents on elastic properties of natural rubber vulcanizates. Plastics, Rubber and Composites Processing and Applications, v.19, p.185194, 1993

PRIYADARSHAN, P.M.; SASIKUMAR, S.; GONÇALVES, P. de S. Phenological changes in Hevea brasiliensis under differential geoclimates. The Planter, v.77, p.447-459, 2001.

SERRES, E.; LACROTTE, R.; PREVOT, J.C.; CLEMENT, A.; COMMERE, J.; JACOB, J.L. Metabolic aspects of latex regeneration in situ for three Hevea clones. Indian Journal of Natural Rubber Research, v.7, p.72-88, 1994.

VAN GILS, G.E. Studies of the viscosity of latex. I: Influence of the dry rubber content. Archives Rubberculture, v.28, p.61 68, 1951.

YIP, E. Clonal characterisation of latex and rubber properties. Journal of Natural Rubber Research, v.5, p.52-80, 1990.

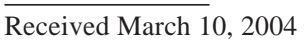

Accepted February 18, 2005 